\title{
Terapia com Células-Tronco: Esperança ou Novo Marketing?
}

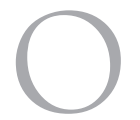

uso de células-tronco embrionárias tem sido mostrado como a próxima fase na luta contra as doenças degenerativas e debilitantes, tais como diabetes, doenças cardíacas ou doença de Parkinson. Freqüentemente temos na mídia, nos websites notícias novas e promocionais sempre transmitindo de alguma maneira que essa terapia é segura e já disponível para uso imediato.

A $\boldsymbol{R} \boldsymbol{B R}$ inicia neste número, com o artigo do Prof. Dr. Júlio C. Voltarelli e colaboradores, "Transplante de CélulasTronco Hematopoéticas em Doenças Reumáticas - Parte 1: Experiência Internacional”(1) apresentando os resultados, nacionais e internacionais, desta nova e valiosa ferramenta no manuseio de doenças reumatológicas graves e refratárias à terapia tradicional, especialmente no lúpus eritematoso sistêmico, na artrite reumatóide e na esclerose sistêmica, um momento para reflexão desse procedimento.

Em junho deste ano foi realizado na Europa um plebiscito para o uso da terapia com células-tronco. Anteriormente, ocorreu um amplo debate com discussão do significado desse novo manuseio terapêutico, nos diversos veículos de comunicação. Em muitos países não foi aprovado o uso de células-tronco embrionárias, especialmente porque não estavam suficientemente claras as implicações éticas devidas, por exemplo, à globalização de espermatozóides tornando possível e questionável esse tratamento, como também a própria expressão genética não definida nas células embrionárias (doenças auto-imunes, malignidades, etc.) e finalmente o uso prematuro dessa nova terapia pode colocar

\section{REFERÊNCIAS}

1. Voltarelli JC, Stracieri ABPL, Oliveira MCB, et al: Transplante de células-tronco hematopoéticas em Doenças Reumáticas - Parte 1: experiência internacional. Rev Bras Reumatol 45: 229-41, 2005.

2. Mervis J: The hunt for a new drug: five views from inside. Science 309: 5735, 722-5, 2005. pacientes em risco de doenças viróticas: uma cultura de células-tronco permitiria que uma linhagem singular de células fosse utilizada em centenas de pacientes ampliando assim o risco de transmissão.

Atualmente, as indústrias de pesquisas farmacêuticas não trabalham mais com um produto feito. Em vez disso, a grande maioria pesquisa em um nível mais básico, procurando alvos potenciais, sintetizando substâncias que atuam em tais alvos terapeuticamente e finalizam fazendo um composto aceitável( ${ }^{(2)}$. Porém, a segurança e qualidade devem ser bem avaliadas antes que esse tratamento possa realmente beneficiar o paciente.

Seria proveitosa a formação de um grupo colaborativo usando um sistema de codificação específica (eventos adversos, doadores, receptores e testes laboratoriais) com a finalidade de orientar a formação de diretrizes para divulgar e aplicar os resultados. Assim, evita-se o que ocorre na Índia ${ }^{(3)}$ e na Rússia ${ }^{(4)}$ com a existência de diversas clínicas oferecendo cura pela terapia das células-tronco para um número infinito de doenças.

A urgência não é desculpa para a ciência. Em outras palavras, esperamos que um possível insucesso financeiro de alguma indústria farmacêutica na pesquisa com célulastronco não derrube tão promissora tecnologia terapêutica.

Fernando S. Cavalcanti Presidente da Sociedade Brasileira de Reumatologia

3. Jayarama, KS: Indian regulations fail to monitor growing stem-cell use in clinicas. Nature 17: 434, 259, 2005.

4. Danilova M: Stem cell craze spreads in Russia. Associated Press: http://apnews.myway.com/articles/20050314/D88QNPG80.html 